\title{
EXPLORING THE LINKAGES BETWEEN PROJECT MANAGERS' MINDSET BEHAVIOUR AND PROJECT LEADERSHIP STYLE IN THE GHANAIAN CONSTRUCTION INDUSTRY
}

\begin{abstract}
Purpose: Leadership encapsulates a process of influencing others to understand what needs to be done and how it can be done. The related area of mindset behaviour which moderates leadership styles adopted in various industries has hitherto received scant academic attention in a construction context. This paper thus explores the linkages between project manager's mindset behaviour and project leadership style in the construction industry.
\end{abstract}

Design/Methodology/Approach: Literature reviewed provides the basis for a questionnaire data collection instrument developed to gather primary data from construction professionals in the Ghanaian Construction Industry (GCI). A quantitative research strategy is then adopted using the Relative Importance Index (RII) to determine the level of significance of the leadership and mindset archetypes. A Pearson's correlation test was run to ascertain whether the mindset behaviour of project managers has a significant impact upon the type of leadership style.

Findings: The study's results indicate that democratic, transformational and situational leadership styles were prevalent leadership styles in the GCI. The analysis also revealed that project managers favoured the 'growth mindset' and that furthermore, this style had a moderate positive relationship with democratic and transformational leadership styles. Conversely, a fixed mindset had a low positive relationship with autocratic and situational leadership styles but a low negative relationship with transformational leadership style.

Practical and theoretical implications: This research provides sufficient data for project managers to identify the type of mindset to nurture (the growth mindset is recommended) and the effective leadership style to be employed. This study engenders wider discussion on mindset behaviour and project leadership style in developing countries. Moreover, the findings present policy makers and practitioners with the leadership styles to promote and develop (democratic, transformational and situational) and mindset behaviour (growth mindset) to ensure project success in Ghana and other developing countries.

Originality/value: This research represents the first comprehensive study appraising the linkages between project manager's mindset behaviour and project leadership style in the construction industry. Empirical data presented bridges the identified knowledge gap that exists on the lack of theoretical understanding of the influence that project managers' mindset has on leadership styles in the GCI.

Keywords: Construction, Leadership Style, Mindset Behaviour, Project Managers, Growth Mindset, Fixed Mindset

Paper type: Research Paper 


\section{INTRODUCTION}

The construction sector plays an essential role in building necessary infrastructure to facilitate economic growth and social equality in emerging and developing economics (Ofori, 2006; Winch, 2010; Owusu-Manu et al., 2019). In emerging economies, the sector contributes to $80 \%$ in gross equity assets, $10 \%$ in Gross Domestic Products (GDP) and over $50 \%$ in employment opportunities. However, Kissi et al. (2019) assert that the sector is beset with high risk situations that affect projects and therefore, demands systematic processes to meet project objectives and ensure profitability. Ofori (2000) stressed that the industry faces considerable problems and challenges globally. Within developing countries, macro challenges include: socio-economic stress; lingering resource shortages; institutional weaknesses; and a general inability to deal with issues head-on. Other industry specific micro issues include: no performance liability; low-fixed capital requirements; unpredictable weather; seasonal effects; uncertain ground conditions; cost overruns; and government interventions in project delays (Hughes and Hillerbrandt, 2003; Kissi et al., 2019). The construction industry is a human endeavour comprising of a plethora of interrelated tasks drawn from different sectors (Ofori, 2012). However, the global construction industry and the prodigious complexity of mega construction projects increases at an alarming rate; leading to calls for efficient and effective project managers and the development of their leadership skills (Suresh et al., 2009; Al Kazaz and Shibani, 2016). Within developing countries, Ofori and Toor (2012) proposed that effective leadership is quintessentially important to mitigating the risk of project failure. Al Kazaz and Shibani (2016) assert that technical and managerial skills can be substituted or supplemented by leadership skills. Although, there are increasing demands for effective sector leadership, defining and delineating one particular leadership style that best fits all situations is 
problematic because construction projects are bespoke (Randeree and Ghaffar, 2012; Tabassi and Bakar, 2010). Several authors concur that although the industry stands to benefit from effective leadership, paradoxically a paucity of studies in a construction and/or civil engineering context exists (Odusami et al., 2003; Toor and Ofori, 2008; Tabassi and Bakar, 2010).

Leadership is a key success factor in every endeavour that involves collaboration of people and is important in all fields of human endeavour (Ofori and Toor, 2012). Leadership is the process of influencing others to understand what needs to be done and how it can be done. In a construction context, leadership coordinates and motivates various stakeholders (e.g. the client, contractors, designers and subcontractors) to successfully deliver a project (Morris, 2004). Heslin and Keating (2017) assert that leadership styles can be improved through the effective development of leaders; thus, leaders should be embedded in a continuous learning mode (Ashford and DeRue, 2012). Project managers need effective leadership style to manage changes that occur on a project and augment project performance (Bejestani, 2011). Demand for leadership in project management continues to grow unabated because it is an important contributor to project success. For example, Al Kazaz and Shibani (2016) emphasized the leadership role of project managers and its impact on performance in the rapidly expanding Dubai construction industry. The study's results $(\mathrm{ibid})$ revealed that leadership skills are a major factor that differentiates between effective leaders and managers. This positively impacts the overall performance and success of construction projects. Construction organisations are thus in search of professionals with effective leadership and management skills in addition to technical experience which is equally significant (Al Kazaz and Shibani, 2016). Peculiarities of construction processes and projects make leadership even more essential. Effective 
leadership goes some way to providing viable solutions to mitigating the problems experienced in developing countries (Ofori and Toor, 2012). Tabassi and Bakar (2009) stress that many of the problems experienced on construction projects can be traced to the insufficient competencies and/or inappropriate leadership style of project managers. Day et al. (2014) emphasize the need to consider leadership and its development holistically, taking into cognizance the dominant role of behaviour patterns influenced by mindset. The study by Kramer (2016), proposed that leader development should focus on transforming mindsets more than skillsets - this promotes flexible adaption to current innovations and creativity in leadership (Walter, 2016).

Psychologists state that mindsets encapsulate people's lay beliefs about the nature of human attributes, such as intelligence or personality (Dweck, 2012). There have been various studies on mindset and how it affects human behaviour, self-regulation and other facets of human development as well as how mindset affects the leader development process (Suresh et al., 2009; Heslin and Keating, 2017). Day et al. (2014) reviewed 25 years of research and theory on leadership but failed to explore the relationship between mindset and leadership. Heslin and Keating (2017) investigated the role of mindsets in derailing and experiential development but again failed to ascertain the typologies of mindset and leadership and how they interrelate. From the prevailing discourse, it is clear that there is growing interest in research in this emerging discipline of the psychology of project success (Suresh et al., 2009; Ofori and Toor, 2012; Day et al., 2014; Heslin and Keating, 2017). However, little research has been undertaken to explore the intricate relationship between project manager's mindset behaviour and project leadership style in the construction industry. Hence, this research seeks to assess the possible influence of a manager's mindset behaviour has on their leadership style in the construction industry. Other concomitant 
objectives are to identify the prevalent leadership archetypes and mindset behaviour in the GCI. This paper is structured as follows: a brief a review of extant literature on mindset behaviour and leadership typologies is conducted. Such work provides the basis for transferring existing knowledge from other more advanced disciplines to a less advanced construction context; the research methodology employed is elaborated upon prior to discussing the emergent findings; and the work concludes with recommendations and directions for future research.

\section{CONCEPTUALIZING MINDSET BEHAVIOUR OF PROJECT MANAGERS}

Mann (2018) summarizes mindset as the way in which people approach learning, failure and success, whereas Mercer and Ryan (2009) define mindset as the fundamental presumptions people make about their various attributes. Dweck (2006) asserts that the impact of mindset beliefs is enormous because they determine our behaviour and how humans handle failures and challenges among others. Dweck (2006) further asserted that differences in mindset are influenced by: an individual's education and environment; and other people (including management, coaches, partners, friends and staff) - albeit ultimately, mindset is a personal choice. According to Hochanadel and Finamore (2015), people perceive their ability as malleable (i.e. changeable or innate) or unchangeable depending on their type of mindset. Dweck (2013) asserted that successful people relish learning, search for challenges, cherish effort and persevere in the face of hindrances and setbacks.

\section{EXPLAINING THE TWO SIDES OF THE COIN: GROWTH AND FIXED MINDSET}

Two dichotomous typologies of mindset are apparent and these affects how people think about their abilities and the way they live their lives: growth mindset (incremental theory) 
and fixed mindset (entity theory) (Chase, 2010; Dweck, 2013). Mercer and Ryan (2009) found that people's mindset does not form a paradox but a person may have either a fixed mindset or growth mindset in distinct situations.

People with a fixed mindset believe their abilities and intelligence are innate and fixed traits but also believe that intelligence, personality and character occur naturally (Dweck, 2013). Hence, this philosophical stance asserts that individuals are born with abilities and intelligence that are static and cannot be developed (Dweck, 2006; Mercer and Ryan, 2009). Dweck (2006) hypothesizes that people with a fixed mindset actively seek to prove and confirm their richly endowed intelligence, character and personality. A fixed mindset tendency believes that either it has what it takes to succeed or it do not, and less effort is needed if one has the innate capacity to succeed. When failure is encountered, a fixed mindset gives up and seeks other opportunities because failure is perceived as a threat that questions the notion of presumed fixed abilities.

However, Dweck (2006) situates the passion to stretch oneself and stick to the process even when beset by difficulties tougher as the earmark of growth mindset. People with a growth mindset believe intelligence, personality and character can develop through effort, dedication and perseverance. They believe in progress and that the innate potential of mankind cannot be determined precisely and can be improved over time through learning and hard work. They prove resilient when faced with setbacks and failure, and never see them as threat but rather as an opportunity to grow and develop. The only drawback of a growth mindset is that people tend to hold firm to something they really cannot see. Table I presents a summary of the difference between the growth and fixed mindsets.

\section{<Insert Table I here>}




\section{CONCEPTUAL REVIEW OF PROJECT MANAGERS LEADERSHIP STYLE}

Leadership remains the most important aspect of management because it is prominent for organisations to spell out how goals are to be pursued and attaining (Dartey-Baah, 2014). However, Dartey-Baah and Addo (2018) found that the conceptual definition of leadership remains contestable and is difficult to define. Leadership is however a process whereby the leader influences the behaviour of followers towards the organization's achievement goals (Voon et al., 2011). Agbozo (2018) identified common themes in defining leadership viz: leadership is a group occurrence (i.e. there is a relation between the leader and the followers); leadership occurs in a setting either in a group or organisation; and leadership involves influence (i.e. a leader alter the actions and thinking of others (followers) in a specific direction).

Turner and Müller (2005) assert that project managers prefer task-oriented to peopleoriented leadership styles but in later research, also attribute project managers' leadership style with project type and their combined impact upon project success (Müller and Turner, 2006). Larson and Gray (2014) also viewed that a project manager's effectiveness is contingent upon a host of specific 'situational' circumstances and the team's characteristics hence, a universal definition is impossible to derive. Novo et al. (2017) delineate that project managers' leadership styles, behaviours and attributes are critical to the success of daily activities. For example, Ofori (2006) proposed a shift in the way project managers' function and lead projects to enhance project success. Toor and Ofori (2007) affirmed that research in the construction industry is beginning to pay more attention to project leadership. Jiang (2014) corroborated this earlier work and established a relationship between a project managers' leadership style and its influence, or even controls over project success factors. 


\section{ARCHETYPES LEADERSHIP STYLES OF PROJECT MANAGERS.}

Xie et al. (2018) defined leadership style as a changeless behavioural model and trait that the leader exhibits. Previous literature has discussed six archetypes of leadership styles that are adopted under differing circumstances, viz: situational leader (contingency theorist); autocratic leader; democratic leader; laissez-faire leader; transformational leader; and transactional leader (cf. Evans and Evans, 2002; Bartol et al., 2003; Sims et al., 2009; Chemers, 2014; Dartey-Baah and Ampofo, 2015; Sousa and Rocha, 2019) - refer to Table II. These studies provide insightful revelations on the various leadership styles but a focus on how project manager's mindset behaviour influences their leadership style is lacking.

\section{$<$ Insert Table II here>}

Underpinning this study, is the transformational leadership style that was first initiated by James Macgregor Burns in 1978, but subsequently, Bass and Avalio pioneered its popularity in organisational psychology and management with further alterations (Jung and Sosik (cited in Odumeru and Ogbonna, 2013). Warrilow (2012) defined transformational leadership as means of instigating positive change in a leader's followers by acting in the best interests of the group. Keegan and Den Hartog (2004) contend that transformational leadership is more appropriate for project managers; a view consistent with Prabhakar (2005) who studied the importance of transformational leadership on project success across twenty-eight nations on switch leadership. The study's results (ibid) indicated that project managers are strong transformational role models and adopt relationship-oriented approaches towards their project team for greater success. Limsila and Ogunlana (2008) and Müller and Turner (2010) corroborated that transformational leadership creates greater effects on a more-demanding project than other leadership 
styles. Research into the transformational leadership style has gained momentum internationally with research being conducted in construction companies in Iran (Rowlinson et al., 1993), and Hong Kong (Kalinowski, 1994).

\section{HOW MINDSET OF PROJECT MANAGERS INFLUENCE THEIR LEADERSHIP STYLE AND SKILLS}

Al Kazaz and Shibani (2016) observed that managers turn into leaders by developing interpersonal skills and establishing an inspirational contact with their subordinates. The authors (ibid) assert that leaders use informal authority with their followers and share leadership that results from knowledge, charisma and effective ideas. Dweck (2006) considers why some organizations progress from good to great while others do not - it was found that successful organizations employ leaders who embrace failures and challenges, maintain faith in a brighter future and hard work till the organisation succeeds. Collins (2001) pondered the question "why effective leaders have these particular qualities" and Dweck (2006) concluded that they have a growth mindset and believe in human development.

Chase (2010) emphasized the critical factors of leadership mindset and the effectiveness and success of a leader. Chase (ibid) further advocated that leadership programmes and coaching education should help leaders and coaches to develop a growth mindset about their abilities and skills - and contended that the ability to lead can be learnt. According to Ismail and Fathi (2019), project managers must adapt different leadership styles at different stages of a project life cycle because leadership is not a one size fits all concept. 


\section{RESEARCH APPROACH}

This study adopted an empirical quantitative approach to collect and analyse primary data (Bryman, 2004; Edwards et al., 2020). Because existing theories obtained extant literature informed research presuppositions, a deductive approach was adopted to test these theories (Creswell, 2003) and generate inference that draws conclusions about project managers' mindset behaviour and leadership styles in the GCI. Adopting relevant theories from extant literature and applying them in deductive scientific investigations is a widely established approach within prevailing construction management and civil engineering literature (Edwards et al., 2019; Olanrewaju et al., 2020). This research approach is also consistent with Nakano and Muniz Jr. (2018) who agreed that a literature review is fundamental to unveiling theory(ies) that underpins or clarifies the concepts of a study. Hereafter, statistical techniques were used to draw diverse meanings and interpretation within the context of the already existing theoretical framework.

The target population consisted of project managers, quantity surveyors, architects and engineers employed in management positions in contractor organisations (D1K1-D2K2) in Ghana's construction industry. The choice of these professionals in the category of project management in Ghana is consistent with previous and ongoing studies in the area (Ahadzie, 2007; Ahadzie et al., 2012). In Ghana, the Ministry of Works and Housing grades contractors into categories and financial classes: D1K1-D4K4 (building and civil works); E1-E3 (electrical works); and G1-G2 (plumbing works). Frimpong and Kwasi (2013) state that D2K2 firms undertake projects worth $\$ 250,000-500,000$ and for D1K1 projects over $\$ 500,000$. The study was limited to eligible $\mathrm{D} 1 / \mathrm{K} 1$ and $\mathrm{D} 2 / \mathrm{K} 2$ construction firms and consultancy firms geographically located in Kumasi or Accra and who could exhibit good 
standing in the sector. These two cities are the largest in Ghana and contain most of the construction and consultancy firms that constitute the sample population (Ahadzie, 2007).

The sample size was selected using the purposive and snowball sampling techniques because the lead researcher had scant information about the target population of firms that are scattered across Accra and Kumasi. The non-probability sampling technique (purposive) enabled the researcher to contact known firms who were most likely to participate (Kumar, 2011). According to Rowley (2014), this approach is applicable when the researcher already knows something about the specific cases and deliberately selects specific ones because they are likely to produce the most valuable data. In purposive sampling, the researcher decides what must be known (viz. suitable knowledge and experience) and sets out to find participants who can, and are willing to participate (Lewis and Sheppard, 2006). Neville (2007) stressed that snowball sampling builds up a sample through informants - starting with one person who then suggests the next respondent(s) and so forth. A sample is deemed adequate when all information needed has been obtained. According to Brown (2007), snowball sampling sometimes follows purposive sampling but whilst snowball sampling uses the source of a respondent, purposive sampling does not (Bernard, 2017). Therefore, snowball sampling (which represents a mix between purposive and convenience sampling (Rowley, 2014)), was adopted to identify firms with sufficient innate information and knowledge to positively contribute to the ensuing discourse on leadership in the GCI. A sample size of 100 project managers was accrued - such is consistent with existing literature (Sapnas and Zeller, 2002; Debrah et al., 2020) to allow for sufficient generalisability within the GCI and other developing countries.

Quantitative designs are often characterised by experiments and surveys (Creswell, 2009). This study adopted a survey research design as the basis for assessing the linkages between project 
managers' mindset behaviour and leadership styles in the GCI. A desk survey was first conducted to assist in the development of a field survey a structured questionnaire survey instrument. This questionnaire was then used to gather information via a field survey after an initial pilot survey comprising of five project managers with 10 years' experience to validate the survey instrument. Rowley (2014) asserted that a questionnaire is more appropriate data collection technique when the intent is to capture and measure the frequency of occurrences of opinions, attitudes, experiences, processes, behaviours and predictions. To achieve the research aim and objectives, a comprehensive literature review was undertaken to identify the important variables which need to be tested. The questionnaire was divided into three main sub-instruments, namely: 1) demographic data; 2) leadership styles of project managers; and 3) mindset of project managers - refer to Tables IV and V.

- The demographic data (section 1) collated information such as gender, professional background, age and educational qualifications; cumulatively, this information sought to certify data reliability (cf. Ahadzie, 2007).

- Sections 2 and 3 assessed the linkages between project manager's mindset behaviour and project leadership style. For both sub-instruments, the respondents were asked to rate their perception on a five-point Likert-scale (1=strongly disagree, $2=$ disagree, $3=$ neutral, $4=$ agree, and $5=$ strongly agree).

Descriptive and inferential analysis were used to analyse the respondents' background information (refer to Table III), whilst variables identified were analysed using the relative importance index (RII) and correlation analysis. The Statistical Package for Social Sciences (SPSS) Version 23.0 and Microsoft Excel were used for analysis purposes. 


\section{Survey Administration}

The questionnaires were distributed to professionals in consultancy firms and those in D1/K1 and D2/K2 construction firms who exhibited a prerequisite track record in the management of construction projects. Most questionnaires were sent out, followed-up and retrieved personally albeit, some were administered using Google forms as an online survey due to significant geographical distances involved. Administering questionnaires personally is highly effective as the researcher can clarify any area of ambiguity/uncertainty with respondents and in so doing, secure a maximum response rate (Walliman, 2011). 92 questionnaires were retrieved out of the 100 distributed representing a $92 \%$ response rate which is adequate for academic research aimed at senior management. For example, Baruch (1999) suggested that a 35\% response rate is acceptable.

\section{Data Analysis}

Prior to data analysis, the significance level was set at $95 \%$ confidence interval (based on the five-point Likert scale rating) and a success standard was considered significant if it had a mean $\geq 3.5$ - this mean value is consistent with previous literature (cf. Ahadzie, 2007; Owusu-Manu et al., 2020). Where two or more items have the same mean, the one with the lowest standard deviation is assigned the higher ranking. The standard error is the standard deviation of the sample which means the measure of how probable a sample represents the population (Hassani et al., 2010). The RII was used to determine the level of significance of the leadership and mindset archetypes in the construction industry viz:

$$
R I I=\frac{\sum W}{A \times N}
$$


Where, $\sum W$ - sum of weights given to each variable by respondents, A-Highest rating (i.e.: 5 for this study) and $N$ - total responses. Furthermore, Pearson's correlation test was used to ascertain whether the mindset of project managers have a significant impact upon the type of leadership style. A reliability test was also conducted to check the internal consistency of variables using Cronbach's alpha coefficient - the most widely accepted means of validating reliability (Kumar, 2011). A Cronbach's Alpha coefficient value of 0.816 was attained and confirms internal consistency in accordance with past literature (Tavakol and Dennick, 2011; Taber, 2018).

\section{ANALYSIS AND DISCUSSIONS}

\section{Demographic Data of Respondents}

Information on the respondents' background offers much credence in the data collected. Ahadzie (2007) asserted that demographic data of the respondent gives authenticity and reliability to the data. Further examination of Table III reveals that, $14 \%$ of the respondents have polytechnic qualifications as their highest level of education, $52 \%$ have a degree (BSc), 31\% have a postgraduate degree and 3\% have a professional qualification(s). The majority of respondents therefore, have degree or higher level of education (83\%).

\section{Professional Background and Age}

Table III shows that most respondents (42.2\%) are quantity surveyors, followed by engineers (30.4\%). In terms of age, the majority (38.0\%) fell within the 25-29 years age category with an equal distribution amongst the remaining discrete categories. This data indicates the diversity of professions in the GCI and gives much reliability and credibility to the data collected. 


\section{$<$ Insert Table III here $>$}

Experience wise, examination of Table III shows that the majority of the respondents (36.9\%) have $0-5$ years of experience, $26.1 \%$ have $6-10$ years of experience, $20.6 \%$ have between 11 - 15 years of experience and $16.3 \%$ more than 15 years of experience which made them knowledgeable enough to answer questions posed. The project management role can be undertaken by any of the professionals in the GCI hence, this formed part of the demographic data as the authors probed further into the most significant and intriguing question relevant to this study. The survey revealed a number of respondents who have successfully supervised projects. 78 of the respondents (representing $84.8 \%$ of the sample) have successfully supervised project prior to this study which offers more credence to the data used in this study. Although the remaining $15.2 \%$ have not successfully supervised project prior to this study, they have confirmed that they have been part of a project team.

\section{Ranking of the Leadership Styles}

Leadership plays a crucial role throughout industry the literature reviewed accentuates the demand for leadership skills among key players in the GCI. Six key and thematic clusters of leadership styles were apparent within prevailing literature. Table IV shows the ranking of the various leadership styles among project managers in the GCI.

\section{$<$ Insert Table IV here $>$}

To determine the internal consistency or average correlation of items in the survey's subinstruments (thus, gauging its reliability), the Cronbach's alpha coefficient was computed 
for five sub-categories. This was found to be $0.689(F$-statistic $=2.738$, sig. $=0.029)$ for the democratic leadership style sub-instrument; $0.834(F$-statistic $=5.013$, sig. $=0.001)$ for transformational leadership style; $0.556(F$-statistic $=0.722$, sig. $=0.577)$ for situational leadership style; $0.627(F$-statistic $=44.243$, sig. $=0.000)$ for transactional leadership style; $0.703(\mathrm{~F}$-statistic $=43.523$, sig. $=0.000)$ for laissez faire leadership style; and $0.705(F$ statistic $=57.551$, sig. $=0.000)$ for the autocratic leadership style. Similarly, the 'growth mind-set' and 'fixed mind-set' sub-instruments had coefficients values of $0.874(F$-statistic $=$ 6.526 , sig. $=0.000)$, and $0.703(F$-statistic $=45.523$, sig. $=0.000)$ respectively. These results indicate a high reliability of scales (Nunnally, 1978) and that lower thresholds are sometimes used in the literature (Nunnally, 1978). Discussed below are the three leading leadership styles favoured among project managers in the GCI.

\section{Democratic Leadership Style}

Table IV ranks the leadership styles using the average RII and reveals that, the democratic leadership style was ranked $1^{\text {st }}$ with an average RII of 0.827 , indicating that this was the most prevalent leadership style project managers exhibit on successful construction projects. The five associated variables within this scale had mean scores ranging from 'My team members work together for a common goal' $($ mean $=4.35, \mathrm{RII}=0.870)$ to 'Members of my team are all treated equally' $($ mean $=4.03, \mathrm{RII}=0.807)$. The standard deviations also ranged from 0.748 to 1.013 indicating some higher level of harmony amongst respondents. This finding confirms the earlier work of Randeree and Ghaffar (2012) who found that the democratic leadership style is most preferred leadership style in the construction sector.

\section{Transformational Leadership Style}


The second overall ranked leadership was that of 'transformational leadership' (average RII $=0.811)$. The five associated variables of this scale had mean scores ranging from 'I inspire and motivate my team members (mean $=4.15, \mathrm{RII}=0.830)$ to 'I keep my ego in check as leader' $($ mean $=3.80, \mathrm{RII}=0.761)$. The standard deviations also ranged from 0.721 to 1.051 indicating some higher level of consensus among the respondents. This finding affirms those of Randeree and Ghaffar (2012) that transformational leadership is the second most preferred leadership style in construction organisations. Similarly, in other developing countries, the study by Aga et al. (2018) based on a field survey of 200 development project managers in the Ethiopian Non-Governmental Organization (NGO), found that the project managers' transformational leadership contributes to project success.

\section{Situational Leadership Style}

The third overall ranked leadership style was that of 'situational leadership' (average RII = 0.800). The four associated variables of this scale had mean scores ranging from 'I do not take advantage over my subordinates $($ mean $=4.10, \mathrm{RII}=0.820)$ to 'T'm flexible in carrying out my leadership roles $($ mean $=3.98, \mathrm{RII}=0.796)$. The standard deviations also ranged from 0.784 to 1.005 indicating some higher level of consensus among the respondents. These findings confirm an earlier study by Ismail and Fathi (2019), who averred that project managers must adapt different leadership styles at different stages of the project life cycle as situational contexts change and evolve.

\section{Reliability Analysis}

Mindset is the core of human existence because it informs and influences our perceptions, behaviours, actions and decisions. Due to the significance of mindset and the need for channelling focus of leadership development to mindset development of leaders (cf. Chase, 
2010), this study sought to identify the mindset typologies among project managers and the prevalent mindset typology. RII was used in ranking variables under each of type of mindset (cf. Pell, 2005; Holt, 2014). Furthermore, a reliability test was undertaken to check the internal consistency of variables using Cronbach's alpha coefficient on the responses received before the analysis (Kumar, 2011). Because the characteristics of the two types of mindset are diametrically opposed, their reliability tests were conducted separately to unveil the true accuracy of the test. Examination of Table V shows that the Cronbach's Alpha coefficient values for the 'growth mindset' and 'fixed mindset' sub-instruments were 0.834 and 0.874 respectively and $>0.7$. This shows that the scale adopted for the study is reliable (cf. Nunnally, 1978).

Among the two types of mindset, the most prevalent is the growth mindset that was ranked $1^{\text {st }}$ with an average RII of 0.863 . This confirms Dweck's $(2006 ; 2013)$ assertions of the characteristics of successful people. The GCI has more growth (vis-à-vis fixed) mindset professionals. This findings concurs with Wang and Yuan (2011) who concluded that boldness (an attribute of growth mindset) is one of the important factors that project manager's use to deal with risk-based decision-making processes; moreover, the work Wang and Yuan (2011) asserted that project managers with boldness are capable of taking risks, making challenging decisions and shaping the contractor's style of dealing with critical events. This affirms the need for construction professionals to develop growth mindset.

The fixed mindset was ranked $2^{\text {nd }}$ with an average RII of 0.376 and recorded lower means scores ranging 2.16 and 1.61. Clearly, Ghanaian construction professionals exhibit less of the fixed mindset characteristics and/or there are fewer fixed mindset professionals. This finding supports the work of previous researchers (cf. Mercer and Ryan, 2009; Dweck, 3013). 


\section{<Insert Table V here>}

\section{Correlation Analysis}

Further analysis was undertaken to determine how mindset of project managers influences their leadership style. This was established by correlating two different types of mindsets, namely 'growth' and 'fixed' mindset and the types of leadership styles. Before a correlation test was conducted, the variables on each mindset type and the associated leadership styles were transformed into one variable using Compute Variables in SPSS version 22. Table VI shows the relationship between the mindset typologies and the leadership styles.

\section{<Insert Table VI here>}

Examination of Table VI shows that the growth mindset has a moderate positive relationship with: the democratic leadership style $(r=0.499)$ and with a Pearson correlation value of $.499^{* *}$; and the transformational leadership style $(r=.315)$ which was statistically significant and p-vales $<0.01$. This indicates that the growth mindset has a positive strong influence on the two leadership styles. This implies that most democratic and transformational leaders in the GCI have a growth mindset.

Table VI further shows that, the fixed mindset has a weak positive relationship with situational leadership style and autocratic leadership style with Pearson correlation values of $(r=0.235, n=92, p=0.024<0.05)$, and $(r=0.235, \mathrm{n}=92, p=0.024<0.05)$. It also has a negative relationship with the transformational leadership style with a Pearson correlation $(r=0.205, n=92, p=0.05>0.01)$. This indicates that a fixed mindset does not have strong positive influence on situational leadership style and autocratic leadership style but has 
minimal negative influence on a transformational leadership style. This indicates that these leaders exhibit a fixed mindset in one way or the other.

Moreover, it is evident that the fixed and growth mindsets have negligible relationships with a transactional leadership style, with a Pearson correlation values of $(\mathrm{r}=0.057, \mathrm{n}=$ $92, \mathrm{p}=0.589>0.05)$ and $(r=0.080, \mathrm{n}=92, \mathrm{p}=0.448>0.05)$ respectively, and a laissez faire leadership style with Pearson correlation values of $(\mathrm{r}=0.154, \mathrm{n}=92, p=0.143>0.05)$. and $(r=0.146, \mathrm{n}=92, \mathrm{p}=0.166>0.05)$ respectively. This implies that project managers can be influenced by any of the mindset stated and this affirms the need for the development of a leader's mindset (cf. Chase, 2010).

\section{IMPLICATIONS}

\section{Theoretical/Practical Implications}

Theoretically, this study promotes wider polemic discussion on mindset behaviour and project leadership style in developing countries and specifically, the GCI. Moreover, empirical data provided bridges the identified knowledge gap on the lack of theoretical understanding of the influence of project managers' mindset on leadership styles. This paper could serve as a source of secondary data to further research into mindset behaviour and leadership style in the construction industry and other industrial sectors within developing countries. As a result, the work further contributes to shaping the ensuing discourse on mindset behaviour in the construction industry especially in the context of developing countries.

This paper thus provides sufficient data for project managers to identify the optimum mindset (growth mindset - recommended) to nurture and the effective leadership styles (e.g. 
democratic) to be employed in the construction industry to enhance productivity performance. This study provides fecund results for project managers to develop their growth mindset acumen and illustrates that project managers cannot stagnate by exhibiting a particular leadership style only but rather, utilize a combination of several styles.

The study proposes that the project managers in the construction industry should adopt the democratic leadership, transformative leadership and situational leadership styles in differing situations since one leadership style cannot satisfy the complex and dynamic needs of the industry - this observation being supported by the previous research (cf. Daft, 2003). Leadership is a key factor in ensuring project management success and hence, project managers must constantly develop leadership skills. The growth mindset (vis-à-vis a fixed mindset) will help promote leadership success due to attributes like constant learning and development, openness and team building. In agreement with Limsila and Ogunlana (2008), project managers can adjust their leadership behaviour through the growth mindset to support the project team to exhibit high project performance. The study's findings revealed the dominant leadership styles (i.e., democratic, transformational and situational) and the overriding mindset archetype (growth mindset) adopted by project managers in the GCI.

\section{Managerial/Policy Implications}

This study accentuates the need to develop the mindset behaviour of project managers as it impacts leadership styles. Stakeholders within the GCI are therefore encouraged to divert some of their attention to consider the finer nuances of mindset and how it underpins industry performance. Project managers and stakeholders alike are encouraged to hone 
their leadership skills in order to maximize project success. Moreover, it is suggested that key players in the GCI formulate and organize programmes, seminars among other means to help develop the mindset behaviour of professional practitioners. A concerted effort should be made to sharpen their skills in handling construction projects with the leadership style(s) that best fit the project(s) considering the critical conditions affecting that project(s) (Chase, 2010). Organizations should dedicate more resources towards training and developing the leadership abilities of their professionals rather than just enhancing the technical capabilities. Project failure or poor project performance is attributive to poor leadership skills not just low technical ability, hence the need for leadership development. Developing the growth mindset of a project manager (leader) will engender better leadership development as leadership abilities are not seen as perpetually fixed. The outcomes of this study provide clear directions to policy makers and practitioners on the leadership styles and mindset behaviour to promote and develop to ensure project success in the GCI which can be applicable to other developing countries.

\section{CONCLUSIONS AND RECOMMENDATIONS}

This study explored the linkages between project manager's mindset behaviour and project leadership style in the GCI. The prevailing discourse within literature illustrates a growing interest in research in this emerging discipline of 'psychology of project success'. However, scant research has hitherto been undertaken to explore the intricate relationship between project managers' mindset behaviour and project leadership style in the construction industry hence, buttressing the need for this research to bridge the identified gap. A literature review revealed six typologies of project manager's leadership styles viz: transformational; situational; democratic; laissez-faire; transactional; and autocratic. It was evident that fixed mindset and growth mindset were exhibited by construction project 
managers. The three leading project leadership styles exhibited by project managers were the democratic; transformational and situational. The growth mindset was highly ranked among the study respondents with fixed mindset being ranked lowest by project managers. Moreover, the growth mindset has a moderate positive relationship with the democratic and transformational leadership styles. It was also identified that fixed mindset has a weak positive relationship with situational leadership and autocratic leadership styles. The study's findings were consistent with, and supported by current and ongoing research into mindset behaviour, project psychology, and project leadership by furthering the discussion in the context of GCI which could serve as a lesson for other developing countries.

Despite the advancement of knowledge transpiring from this study, it has its intrinsic limitations. Although this study was conducted in Ghana, lessons learnt could be adapted in understanding the construction leadership and mindset behaviour in other developing countries that share similar characteristics with Ghana. A potential issue relates to statistics adopted and consequently, generated - as the British Prime Minister, Benjamin Disraeli once noted "lies, damn lies and statistics." Specifically, does a correlation prove causality? This work relies upon existing theories within extant literature to augment claims of causation using statistics (a standard approach adopted in various past studies) but ultimately, future work must be conducted to prove the findings definitively via observation and longitudinal studies in practice. Moreover, this research presents the first comprehensive empirical study on construction leadership and mindset behaviour, contributing to the 'construction leadership' body of knowledge. The study's respondents were thus, construction professional in managerial roles (project managers, quantity surveyors, engineers, and architects). Project managers considered in the survey were (or are) project team leaders of various construction projects who were required to identify 
their favoured leadership style and mindset archetype (cf. Hunter et al., 2007). To eliminate sampling biases and error, the study included project managers with a wide range of leadership experience through snowball and purposive sampling but a much wider random sample could have yielded different results. Moreover, the views of other stakeholders in the construction industry (e.g. policy makers, clients, skilled and unskilled labour) were not considered and yet, often they are the ones being led. Finally, the study's respondents were skewed towards male professionals $(82.6 \%)$ - a regrettable indicator that equality remains wanting in Ghana. These identified limitations could form the basis for future studies.

All through the study, a handful of domains were identified to unlock opportunities for further exploration which could provide profuse and fecund results in the study area. It is recommended that future studies should develop a framework for incorporating development of mindset into leadership development programmes. This research can be extended further to look at the mindset and/or leadership and their influence on project success from a particular professional's perspective or a case study on either government projects or private projects. Researchers in other sectors of the economy as well as developing countries could explore this study in their local setting to validate the findings thereof using a more rigorous analysis to underpin the influence. Furthermore, the survey method employed for the study did not consider the verbatim perspectives of the project manager on leadership and mindset, a recommendation for further studies. 


\section{REFERENCES}

Aga, D.A., Noorderhaven, N. and Vallejo, B. (2018), "Transformational leadership and project success: The mediating role of team-building", International Journal of Project Management, Vol. 34, Issue 5, Pg. 806-818.

Agbozo, R.E. (2018). Leadership Styles, Perceived Organisational Politics and Employees' Work Engagement Evidence from Indigenous Ghanaian Banks (Doctoral dissertation, University of Ghana).

Ahadzie, D. K., Kissai, E., and Adjei-Kumi, T. (2012, March). The status of project management practices in the Ghanaian construction industry. In Procs 1st International Conference on Infrastructure Development in Africa (ICIDA), pg. 116.

Ahadzie, D.K. (2007). A Model for Predicting the Performance of Project Managers in Mass House Building Projects in Ghana, PhD. Thesis, University of Wolverhampton.

Al Kazaz, M. and Shibani, A. (2016). The Impact of Managers' Leadership Skills on Construction Project Performance in Dubai (Doctoral dissertation, Master Thesis. Dubai University, UAE).

Ashford, S. J., and DeRue, D. S. (2012). Developing as a leader: The power of mindful engagement. Organizational Dynamics, Vol. 41 Issue 2, pg. 146-154.

Baruch, Y. (1999). Response rate in academic studies-A comparative analysis. Human relations, Vol. 52 Issue 4, pg.421-438.

Bejestani, H. S. (2011). Improving project change management using leadership spirit. iBusiness. Vol. 3 Issue 03, pg.302.

Bernard, H. R. (2017). Research methods in anthropology: Qualitative and quantitative approaches. Rowman \& Littlefield.

Boonyachai, Y. (2011). An investigation of the leadership styles of middle managers in the Thai hotel industry using the MLQ (5X-Short Form) and Hofstede's Cultural Dimension.

Brown, K. M. (2007). Reconciling moral and legal collective entitlement: implications for community-based land reform. Land Use Policy, Vol 24 Issue 4, pg.633-643.

Bryman, A. (2004). Social Research Methods. $2^{\text {nd }}$ Edition, Oxford University Press.

Chase, M.A. (2010). Should coaches believe in innate ability? The importance of leadership mindset. Quest, Vol. 62 Issue 3, pg. 296- 307.

Chemers, M. (2014). An integrative theory of leadership. Psychology Press.

Collins, J. C. (2001). Good to great. \$ c. 
Creswell, J.W. (2003). "Research design Qualitative quantitative and mixed methods Approaches." 2nd ed., SAGE Publications, California.

Creswell, J.W. (2009). "Research Design: Qualitative, Quantitative and Mixed Approaches." $3^{\text {rd }}$ ed., SAGE Publications, California.

Daft, R. (2003). Management, 6th ed. Thompson: South-Western West.

Dartey-Baah, K. (2014). Effective leadership and sustainable development in Africa: are there "really" a link? Journal of Global Responsibility, Vol. 5 Issue 2, pg.203-218.

Dartey-Baah, K. and Addo, S.A. (2018). Charismatic and corrective leadership dimensions as antecedents of employee safety behaviours: A structural model. Leadership \& Organization Development Journal, Vol. 39 Issue 2, pg.186-201.

Dartey-Baah, K. and Ampofo, E.Y. (2015). Examining the influence of transformational and transactional leadership styles on perceived job stress among Ghanaian banking employees. International Journal of Business and Management, Vol. 10 Issue 8, pg.161.

Day, D.V., Fleenor, J.W., Atwater, L.E., Sturm, R.E. and McKee, R.A. (2014). Advances in leader and leadership development: A review of 25 years of research and theory. The leadership quarterly, Vol. 25 Issue 1, pg.63-82

Debrah, C., Owusu-Manu, D., Kissi, E., Oduro-Ofori, E. and Edwards, D.J. (2020). "Barriers to Green Cities Development in Developing Countries: Evidence from Ghana”. Smart and Sustainable Built Environment, https://doi.org/10.1108/SASBE-06-2020-0089

Dweck S., C. (2006). Mindset: THe new psychology of success. 1st ed. New York: Random House Digital.

Dweck, C.S. (2012). Mindsets and human nature: Promoting change in the Middle East, the schoolyard, the racial divide, and willpower. American Psychologist, Vol. 67 Issue 8, pg.614.

Dweck, C.S. (2013). Self-theories: Their role in motivation, personality, and development. Psychology press.

Edwards, D. J., Pärn, E. A., Sing, C. P. and Thwala, W.D. (2019) Risk of excavators overturning: determining horizontal centrifugal force when slewing freely suspended loads. Engineering, Construction and Architectural Management. 26(3), pp. 479-498. DOI: https://doi.org/10.1108/ECAM-03-2018-0125

Edwards, D.J., Rillie, I., Chileshe, N. Lai, J., Hossieni , M. Reza, and Thwala, W.D. (2020) A field survey of hand-arm vibration exposure in the UK utilities sector, Engineering, 
Construction and Architectural Management. DOI: https://doi.org/10.1108/ECAM09-2019-0518

Frimpong, S. K., and Kwasi, O. O. (2013). Analyzing the risk of investment in the construction industry of Ghana. European Journal of Business and Management, Vol. 5 Issue 2, pg.21-129.

Hassani, H., Ghodsi, M., and Howell, G. (2010). A note on standard deviation and standard error. Teaching Mathematics and its Apglications: An International Journal of the IMA, Vol. 29 Issue 2, pg.108-112.

Heslin, P. A. and Keating, L. (2017). In Learning Mode? The Role of Mindsets in Derailing and Enabling Experimential Leadership Development. The Leadership Quarterly Vol. 28 Issue 3, pg.367-384.

Hochanadel, A. and Finamore, D. (2015). Fixed and growth mindset in education and how grit helps students persist in the face of adversity. Journal of International Education Research, Vol. 11 Issue 1, pg.47-50

Holt, G. D. (2014). Asking questions, analysing answers: relative importance revisited. Construction Innovation. Vol. 14 Issue. 1, pg.2-16

Hughes, W.P. and Hillebrandt, P.M. (2003) Construction industry: Historical overview and technological change. In: Mokyr, J. (ed.) The Oxford Encyclopedia of Economic History. Oxford University Press, Oxford, pg.504-512. ISBN 9780195105070

Hunter, S. T., Bedell-Avers, K. E., and Mumford, M. D. (2007). The typical leadership study: Assumptions, implications, and potential remedies. The Leadership Quarterly, 18(5), pg.435-446.

Ismail, M., and Fathi, M. S. (2019). Leadership in Construction: Leadership Styles Practiced in Construction Project-A Review.

Jiang, J. (2014). The study of the relationship between leadership style and project success. American Journal of Trade and Policy, Vol. 1 Issue 1, pg.51-55.

Keegan, A. E., and Den Hartog, D. N. (2004). Transformational leadership in a projectbased environment: a comparative study of the leadership styles of project managers and line managers. International journal of project management, Vol. 22 Issue 8, pg.609-617.

Kissi, E., Amoah, P., Ahadzie, D. K., and Debrah, C. (2019). Critical Risk Factors in Pricing of Construction Resources of SME Construction Firms in Ghana. 43rd AUBEA, pg.341-350. 
Kramer, R. (2016). From skillset to mindset: a new paradigm for leader development. Public Administration Issues, no 5 (Special Issue, electronic edition), pg.26-45 (in English)

Kumar, R. (2011). Research methodology: A step-by-step guide for beginners. Sage Publications Limited.

Larson, E. W., and Gray, C. F. (2014). Project Management: The Managerial Process with MS Project.

Lewis, J. L., and Sheppard, S. R. (2006). Culture and communication: can landscape visualization improve forest management consultation with indigenous communities? Landscape and Urban Planning, Vol. 77 Issue 3, pg.291-313.

Limsila, K., and Ogunlana, S. O. (2008). Performance and leadership outcome correlates of leadership styles and subordinate commitment. Engineering, construction and architectural management, Vol. 15 Issue 2, pg.164-184.

Mann, A.W. (2018). Free your mindset. In Future First, Vol. 40, Issue 51, pg.40-51, Routledge.

Mercer, S. and Ryan, S. (2009). A mindset for EFL: Learners' beliefs about the role of natural talent. ELT journal, Vol. 64 Issue 4, pg.436-444.

Morris, P.W. (2004). The Wiley guide to managing projects. John Wiley and Sons Ltd, USA.

Müller, R., and Turner, J. R. (2007). Matching the project manager's leadership style to project type. International journal of project management, Vol. 25 Issue 1, pg.21-32.

Müller, R., and Turner, R. (2010). Leadership competency profiles of successful project managers. International Journal of project management, Vol. 28 Issue 5, pg.437-448.

Nakano, D., and Muniz Jr, J. (2018). "Writing the literature review for empirical papers." Production, 28.

Novo, B., Landis, E. A., and Haley, M. L. (2017). Leadership and its role in the success of project management. Journal of Leadership, Accountability and Ethics, Vol. 14 Issue 1.

Nunnally, J., (1978), "Psychometric Theory", 2nd ed., McGraw-Hill, New York, NY.

Odumeru, J.A. and Ogbonna, I.G. (2013). Transformational vs. transactional leadership theories: Evidence in literature. International Review of Management and Business Research, Vol. 2 Issue 2, pg.355. 
Odusami, K. T., Iyagba, R. R. O., and Omirin, M. M. (2003). The relationship between project leadership, team composition and construction project performance in Nigeria. International journal of project management, Vol. 21 Issue 7, pg.519-527.

Ofori, G. (2000, November). Challenges of construction industries in developing countries: Lessons from various countries. In 2 nd international conference on construction in developing countries: challenges facing the construction industry in developing countries, Gaborone, November, Vol. 5, Issue 24, pg.15-17).

Ofori, G. (2006). Construction Industry in Developing Countries: A research Agenda. Journal of Construction in Developing countries, Vol. 11 Issue 1, pg.51-62.

Ofori, G. (2012). Developing the Construction Industry in Ghana: the case for a central agency. A concept paper prepared for improving the construction industry in Ghana. National University of Singapore, pg.3-18.

Ofori, G., and Toor, S. U. R. (2012). Leadership and Construction Industry Development in Developing Countries. Journal of Construction in Developing Countries, Vol. 17 Issue 1, pg.1-21.

Olanrewaju, O., Chileshe, N. and Edwards, D. J. (2020) Estimating on-site emissions during ready mixed concrete (RMC) delivery: A methodology. Case Studies in Construction Materials. DOI: https://doi.org/10.1016/j.cscm.2020.e00439

Owusu-Manu, D., Jehuri, A., Edwards, D. J., Boateng, F. and Asumadu, G. (2019) The impact of infrastructure development on economic growth in Sub-saharan Africa with special focus on Ghana. Journal of Financial Management of Property and Construction, 24(3), pp. 253-273. DOI: https://doi.org/10.1108/JFMPC-09-2018-0050

Owusu-Manu, D., Debrah, C., Oduro-Ofori, E., Edwards, D.J. Antwi-Afari, P., (2020). Attributable Indicators for Measuring the Level of Greenness of Cities in Developing Countries: Lessons from Ghana. Journal of Engineering Design and Technology. https://doi.org/10.1108/JEDT-06-2020-0257

Pell, G. (2005), "Use and misuse of Likert scales”, Medical Education, Vol. 39 Issue. 9, pg. 970.

Prabhakar, G. P. (2005). Switch leadership in projects an empirical study reflecting the importance of transformational leadership on project success across twenty-eight nations. Project Management Journal, Vol. 36 Issue 4, pg.53-60. 
Randeree, K. and Ghaffar Chaudhry, A. (2012). Leadership-style, satisfaction and commitment: An exploration in the United Arab Emirates' construction sector. Engineering, Construction and Architectural Management, Vol. 19 Issue 1, pg.61-85.

Rowley, J. (2014) "Designing and using research questionnaires", Management Research Review, Vol. 37 Issue: 3, pg.308-330.

Rowlinson, S., Ho, T. K., and Po-Hung, Y. (1993). Leadership style of construction managers in Hong Kong. Construction Management and Economics, Vol. 11 Issue 6, pg.455-465.

Sims Jr, H.P., Faraj, S. and Yun, S. (2009). When should a leader be directive or empowering? How to develop your own situational theory of leadership. Business Horizons, Vol. 52 Issue 2, pg.149-158.

Suresh, S.J.R.S., Roden, S.J., Al-Khafaji, A.W. and Renukapga, S. (2009, September). The key drivers for leadership skills development practices in the UK construction industry: An empirical study. In Construction and Building Research Conference (COBRA).

Tabassi, A. A and Bakar, A. H. A. (2010). Towards assessing the leadership style and quality of transformational leadership. Journal of Technology Management in China.

Tabassi, A. A., and Bakar, A. A. (2009). Training, motivation, and performance: The case of human resource management in construction projects in Mashhad, Iran. International journal of project management, Vol. 27 Issue 5, pg.471-480.

Taber, K. S. (2018). The use of Cronbach's alpha when developing and reporting research instruments in science education. Research in Science Education, Vol. 48 Issue 6, pg. $1273-1296$.

Tavakol, M., and Dennick, R. (2011). Making sense of Cronbach's alpha. International journal of medical education, Vol. 2, pg. 53.

Toor, S.R. and Ofori, G. (2008), "Leadership for future construction industry: Agenda for authentic leadership", International Journal of Project Management, Vol. 26 No. 6, pg.620-630

Turner, J. R., and Müller, R. (2005). The project manager's leadership style as a success factor on projects: A literature review. Project management journal, Vol. 36 Issue 2, pg. $49-61$. 
Voon, M.L., Lo, M.C., Ngui, K.S. and Ayob, N.B. (2011). The influence of leadership styles on employees' job satisfaction in public sector organizations in Malaysia. International Journal of Business, Management and Social Sciences, Vol. 2 Issue 1, pg.24-32.

Walliman, N. (2011). Research Methods the basic, Routledge, London.

Walter, S. L. (2016). Who develops? Understanding the role of leadership mindset in developmental opportunities. PhD (Doctor of Philosophy) thesis, University of Iowa, 2016.

Wang, J. and Yuan, H. (2011). Factors affecting contractors' risk attitudes in construction projects: Case study from China. International Journal of Project Management, Vol. 29 Issue 2, pg.209-219.

Warrilow, S. (2012). Transformational leadership theory-The 4 key components in leading change \& managing change. Harvard Business Review, Vol. 2 Issue 3, pg.101-104.

Williams, B., Onsman, A. and Brown, T. (2010). Exploratory factor analysis: A five-step guide for novices. Australasian Journal of Paramedicine, Vol. 8 Issue 3.

Xie, Y., Xue, W., Li, L., Wang, A., Chen, Y., Zheng, Q., Wang, Y. and Li, X. (2018). Leadership style and innovation atmosphere in enterprises: An empirical study. Technological Forecasting and Social Change 
Table I: Difference between Growth and Fixed Mindsets

\begin{tabular}{|c|c|c|}
\hline $\mathbf{S} / \mathbf{N}$ & Growth Mindset & Fixed mindset \\
\hline 1 & Embrace challenges. & Avoid challenges. \\
\hline 2 & Learn from feedback and criticism. & Ignore feedback and criticism. \\
\hline 3 & $\begin{array}{l}\text { Believe intelligence and talent can be } \\
\text { developed. }\end{array}$ & Believe intelligence and talent are fixed \\
\hline 4 & $\begin{array}{l}\text { Never give up but keep on trying harder } \\
\text { and learning till the goal is achieved }\end{array}$ & Give up easily when faced with setbacks. \\
\hline 5 & Inspired by others success & $\begin{array}{l}\text { Feel insecure and tend to sabotage } \\
\text { others who are successful }\end{array}$ \\
\hline 6 & $\begin{array}{l}\text { Lifetime learners (learn from failures and } \\
\text { other means to improve themselves) }\end{array}$ & $\begin{array}{l}\text { Failure to learn from their failures and } \\
\text { get stuck. }\end{array}$ \\
\hline
\end{tabular}

Source: Author's construct (2019) 
Table II: Characteristics of Leadership Typologies

\begin{tabular}{|c|c|c|}
\hline Leadership Style & Description & References \\
\hline $\begin{array}{l}\text { Situational } \\
\text { Leader/Contingency } \\
\text { Theorist }\end{array}$ & $\begin{array}{l}\text { - The followers' maturity level of task-relevant determines the leader's behaviour in a situation. } \\
\text { - The leader's effectiveness is linked to how he or she comprehends the situation. } \\
\text { - The leadership approach and leader's behaviour is based on the situations. } \\
\text { - No one particular leadership will be suitable for all situations. }\end{array}$ & $\begin{array}{l}\text { Bartol et } \quad \text { al. } \\
\text { (2003); Sims et al. } \\
(2009) ; \quad \text { Chemers } \\
(2014)\end{array}$ \\
\hline Autocratic Leader & $\begin{array}{l}\text { - Leaders set schedules, decide the policies of the group, assign duties to the members, and make decisions } \\
\text { on behalf of the group without consulting the members. } \\
\text { - The leader is responsible for the performance of the group but accepts little suggestions from them and } \\
\text { mostly communication channel is between group and leader but rarely among members of the group } \\
\text { - This leadership style is suitable when quick decisions need to be made in the case of emergency, when } \\
\text { team input and agreement are not necessary }\end{array}$ & $\begin{array}{l}\text { Evans and Evans } \\
\text { (2002); Sousa and } \\
\text { Rocha (2019) }\end{array}$ \\
\hline Democratic Leader & $\begin{array}{l}\text { - There is follower's involvement in goal setting, decision making. } \\
\text { - leaders stimulate self-direction and self-actualisation of group members by seeking their opinions in the } \\
\text { decision-making process, setting of goals, strategies and procedures though the leader makes the final } \\
\text { decision. } \\
\text { - Leader encourages team creativity and promotes high membership engagement which leads to job } \\
\text { satisfaction and high productivity among team members. }\end{array}$ & $\begin{array}{l}\text { Bartol et al. } \\
\text { (2003); } \\
\text { Boonyachai, } \\
\text { (2011); Sousa and } \\
\text { Rocha (2019). }\end{array}$ \\
\hline $\begin{array}{l}\text { Laissez-Faire } \\
\text { Leader }\end{array}$ & $\begin{array}{l}\text { - Leader avoids making decisions, relinquish responsibility and does not use authority. } \\
\text { - The leader has little authority and evaluates and criticise followers very little. } \\
\text { - This leadership style promotes creativity, innovation and researches among followers and is effective } \\
\text { where followers have knowledge, skills, or self-motivation to work efficiently }\end{array}$ & $\begin{array}{l}\text { Bartol et al. } \\
\text { (2003); Sousa and } \\
\text { Rocha (2019). }\end{array}$ \\
\hline $\begin{array}{l}\text { Transformational } \\
\text { Leader }\end{array}$ & $\begin{array}{l}\text { - The leader influence through charisma which is centered on values, belief and mission as well as his or } \\
\text { her high set of standards. } \\
\text { - Invigorate followers by captivating vision, goals and mission, enthusiasm as well as optimism. } \\
\text { - Challenge follower's creativity for problem solving and encourages teamwork. } \\
\text { - Advising, supporting, coaching and caring for individuals. }\end{array}$ & $\begin{array}{l}\text { Warrilow (2012); } \\
\text { Dartey-Baah } \\
\text { and Ampofo } \\
(2015) ; \text { Xie (2018) }\end{array}$ \\
\hline $\begin{array}{l}\text { Transactional } \\
\text { Leader }\end{array}$ & $\begin{array}{l}\text { - Providing roles, clarifies tasks and psychological reward ((strongly encourages adherence of his followers } \\
\text { through both rewards and punishments). } \\
\text { - Active observance by leader to ensure goals is achieved (interested in processes and standards rather } \\
\text { than dynamic ideas) } \\
\text { - Leader intervenes when mistakes occur } \\
\text { - Uses a one-size-fits-all approach to leadership neglecting situational and contextual factors related to } \\
\text { organisational challenges }\end{array}$ & $\begin{array}{lr}\text { Yukl } & \text { and } \\
\text { Mashsud } & (2010) ; \\
\text { Yukl } & (2012) ; \\
\text { Odumeru } & \text { and } \\
\text { Ifeanyi (2013) }\end{array}$ \\
\hline
\end{tabular}

Source: Author's construct (2019) 
Table III: Professional background of respondents

\begin{tabular}{|c|c|c|}
\hline Respondent profile & Frequency & Percent \\
\hline \multicolumn{3}{|l|}{ Gender } \\
\hline Male & 76 & 82.6 \\
\hline Female & 16 & 17.4 \\
\hline Total & 92 & 100.0 \\
\hline \multicolumn{3}{|l|}{ Education qualification } \\
\hline HND (Polytechnic) & 13 & 14.1 \\
\hline BSc/BTech & 48 & 52.2 \\
\hline MSc/MTech & 28 & 30.4 \\
\hline Professional qualification & 3 & 3.3 \\
\hline Total & 92 & 100.0 \\
\hline \multicolumn{3}{|l|}{ Age (Years) } \\
\hline $25-29$ & 35 & 38.0 \\
\hline $30-34$ & 17 & 18.5 \\
\hline $34-39$ & 16 & 17.4 \\
\hline $40-44$ & 13 & 14.1 \\
\hline Above 45 & 11 & 12.0 \\
\hline Total & 92 & 100.0 \\
\hline \multicolumn{3}{|l|}{ Professional background } \\
\hline Engineers & 28 & 30.4 \\
\hline Architects & 12 & 13.1 \\
\hline Quantity surveyors & 39 & 42.4 \\
\hline Project managers & 13 & 14.1 \\
\hline Total & 92 & 100 \\
\hline
\end{tabular}


Table IV: Ranking of the importance of leadership styles of project managers

\begin{tabular}{|c|c|c|c|c|c|c|c|c|c|}
\hline \multirow{2}{*}{ Leadership styles } & \multirow[t]{2}{*}{ Total } & \multirow{2}{*}{$\begin{array}{l}\text { Sum } \\
\left(\sum \mathrm{W}\right)\end{array}$} & \multicolumn{2}{|c|}{ Mean* } & \multirow{2}{*}{ Std dev } & \multirow{2}{*}{ RII } & \multirow{2}{*}{$\mathrm{R}$} & \multirow{2}{*}{ Ave } & \multirow[t]{2}{*}{$\mathrm{OR}^{1}$} \\
\hline & & & Score & Std. error & & & & & \\
\hline \multicolumn{10}{|l|}{ Democratic Leadership $(\alpha=0.689)$} \\
\hline My team members work together for a common goal. & 92 & 400 & 4.35 & 0.078 & 0.748 & 0.870 & 1 & 0.827 & 1 \\
\hline Members of my team feel more engaged in the process. & 92 & 377 & 4.10 & 0.086 & 0.826 & 0.820 & 2 & & \\
\hline Creativity is encouraged and rewarded. & 92 & 377 & 4.10 & 0.086 & 0.826 & 0.820 & 2 & & \\
\hline $\begin{array}{l}\text { I encourage my team members to share their ideas } \\
\text { and opinions, even though I retain the final say over } \\
\text { decisions }\end{array}$ & 92 & 376 & 4.09 & 0.106 & 1.013 & 0.817 & 4 & & \\
\hline Members of my team are all treated equally. & 92 & 371 & 4.03 & 0.089 & 0.857 & 0.807 & 5 & & \\
\hline \multicolumn{10}{|l|}{ Transformational Leadership, $(\alpha=0.834)$} \\
\hline I inspire and motivate my team members. & 92 & 382 & 4.15 & 0.086 & 0.825 & 0.830 & 1 & 0.811 & 2 \\
\hline $\begin{array}{l}\text { I am well organized, self-managed and internally } \\
\text { motivated. }\end{array}$ & 92 & 380 & 4.13 & 0.093 & 0.892 & 0.826 & 2 & & \\
\hline $\begin{array}{l}\text { I take new and innovative ideas from my team } \\
\text { members. }\end{array}$ & 92 & 377 & 4.10 & 0.082 & 0.785 & 0.820 & 3 & & \\
\hline $\begin{array}{l}\text { I set realistic and achievable goals for my team } \\
\text { members. }\end{array}$ & 92 & 376 & 4.09 & 0.076 & 0.721 & 0.817 & 4 & & \\
\hline I keep my ego in check as a leader. & 92 & 350 & 3.80 & 0.110 & 1.051 & 0.761 & 5 & & \\
\hline \multicolumn{10}{|l|}{ Situational Leadership, $(\alpha=0.856)$} \\
\hline I do not take advantage over my subordinates. & 92 & 377 & 4.10 & 0.100 & 0.961 & 0.820 & 1 & 0.800 & 3 \\
\hline I give directives to my subordinates. & 92 & 370 & 4.02 & 0.082 & 0.784 & 0.804 & 2 & & \\
\hline $\begin{array}{l}\text { I involve my subordinates in the decision-making } \\
\text { process. }\end{array}$ & 92 & 368 & 4.00 & 0.097 & 0.926 & 0.800 & 3 & & \\
\hline I am flexible in carrying out my leadership roles. & 92 & 366 & 3.98 & 0.105 & 1.005 & 0.796 & 4 & & \\
\hline \multicolumn{10}{|l|}{ Transactional Leadership, $(\alpha=0.627)$} \\
\hline I am very pragmatic in solving problems. & 92 & 369 & 4.01 & 0.075 & 0.719 & 0.802 & 1 & & \\
\hline I reward hardworking team members and punish the & 92 & 354 & 3.85 & 0.100 & 0.960 & 0.770 & 2 & & 4 \\
\hline
\end{tabular}


lazy ones.

I focus on maintaining the status quo in my

I enjoy routine activities.

I mostly resistant to change.

\section{Laissez Faire Leadership, $(\alpha=0.703)$}

I mostly provide the tools and resources needed for the team.

I hand over power to my team members, but I still

92

345

3.75

0.096

0.921

$\begin{array}{lll}0.750 & 1 & 0.651\end{array}$
take responsibility for the group's decisions and

340

0.108

1.035

0.7392 actions.

I give room for and expect my team members to solve problems on their own.

My team members have complete freedom to make decisions.

I provide very little guidance to my team members.

$92 \quad 326$

326

3.54

0.524

0.919

$0.709 \quad 3$

Autocratic Leadership, $(\alpha=0.705)$

Rules are important and tend to be clearly outlined and communicated.

I rarely trust my team members with decisions or important tasks.

I take almost all of the decisions concerning the project.

I dictate all the work methods and processes.

I do not take suggestions from my team members.

\begin{tabular}{lllllllll}
92 & 356 & 3.87 & 0.094 & 0.904 & 0.774 & 1 & 0.524 & 6 \\
92 & 236 & 2.57 & 0.131 & 1.252 & 0.513 & 2 & & \\
92 & 230 & 2.50 & 0.132 & 1.262 & 0.500 & 3 & \\
& & & & & & & \\
92 & 212 & 2.30 & 0.124 & 1.193 & 0.461 & 4 & \\
92 & 170 & 1.85 & 0.120 & 1.148 & 0.370 & 5 & \\
\hline
\end{tabular}

Source: Author's Field Data (2019); ${ }^{1} \mathrm{OR}=$ Overall ranking*; MS = Mean score based on valid $\mathrm{n}=92$ (list wise), $\mathbf{b}$ mean score of the leadership styles and mind-set variables where $5=$ strongly agree; $4=$ agree; $3=$ neutral; $2=$ disagree; $1=$ strongly disagree. The higher the mean score the more important the variable; RII = Relative importance index; $\alpha=$ Cronbach's Alpha coefficient value 
Table V: Ranking of the importance of the mindsets of project managers

\begin{tabular}{|c|c|c|c|c|c|c|c|c|c|}
\hline \multirow[b]{2}{*}{ Mindset } & \multirow[b]{2}{*}{$\begin{array}{c}\text { Total } \\
(\mathrm{N})\end{array}$} & \multirow[b]{2}{*}{$\begin{array}{l}\text { Sum } \\
\left(\sum W\right)\end{array}$} & \multicolumn{2}{|c|}{ Mean* } & \multirow[b]{2}{*}{$\begin{array}{l}\text { Std } \\
\text { dev }\end{array}$} & \multirow[b]{2}{*}{ RII } & \multirow[b]{2}{*}{ Rank } & \multirow[b]{2}{*}{$\begin{array}{l}\text { Avg } \\
\text { RII }\end{array}$} & \multirow[b]{2}{*}{ OR } \\
\hline & & & $\begin{array}{l}\text { Scor } \\
\text { e }\end{array}$ & $\begin{array}{l}\text { Std. } \\
\text { Error }\end{array}$ & & & & & \\
\hline \multicolumn{10}{|l|}{ Growth Mindset ( $\alpha=0.834)$} \\
\hline $\begin{array}{l}\text { I am a lifetime learner learning from my } \\
\text { failures and other means to improve myself. }\end{array}$ & 92 & 409 & 4.45 & 0.068 & 0.652 & 0.889 & 1 & \multirow{6}{*}{0.863} & \multirow{6}{*}{1} \\
\hline $\begin{array}{l}\text { I am mostly inspired by other people } \\
\text { successes. }\end{array}$ & 92 & 404 & 4.39 & 0.067 & 0.645 & 0.878 & 2 & & \\
\hline $\begin{array}{l}\text { I never give up but keep on trying harder and } \\
\text { learning till my goal is achieved. }\end{array}$ & 92 & 402 & 4.37 & 0.077 & 0.737 & 0.874 & 3 & & \\
\hline I learn from feedbacks and criticisms. & 92 & 393 & 4.27 & 0.071 & 0.681 & 0.854 & 4 & & \\
\hline $\begin{array}{l}\text { I believe intelligence and talents can be } \\
\text { developed. }\end{array}$ & 92 & 392 & 4.26 & 0.083 & 0.797 & 0.852 & 5 & & \\
\hline I am willing to fully embrace challenges. & 92 & 382 & 4.15 & 0.079 & 0.755 & 0.830 & 6 & & \\
\hline \multicolumn{10}{|l|}{ Fixed Mindset $(\alpha=0.874)$} \\
\hline I believe intelligence and talent are fixed. & 92 & 199 & 2.16 & 0.127 & 1.216 & 0.433 & 1 & \multirow{6}{*}{0.376} & \multirow{6}{*}{2} \\
\hline I avoid challenges. & 92 & 186 & 2.02 & 0.111 & 1.069 & 0.404 & 2 & & \\
\hline I often ignore feedbacks and criticisms. & 92 & 172 & 1.87 & 0.094 & 0.904 & 0.374 & 3 & & \\
\hline $\begin{array}{l}\text { I tend to give up easily when overwhelm with } \\
\text { setbacks. }\end{array}$ & 92 & 170 & 1.85 & 0.108 & 1.037 & 0.370 & 4 & & \\
\hline $\begin{array}{l}\text { I tend not to learn from my failures and } \\
\text { sometimes get stuck. }\end{array}$ & 92 & 163 & 1.77 & 0.121 & 1.159 & 0.354 & 5 & & \\
\hline $\begin{array}{l}\text { I feel insecure and tend to sabotage others } \\
\text { who are successful. }\end{array}$ & 92 & 148 & 1.61 & 0.102 & 0.983 & 0.321 & 6 & & \\
\hline
\end{tabular}

Source: Author's Field data (2019); *; MS = Mean score based on valid n =92 (list wise), ${ }^{\mathbf{b}}$ mean score of the leadership styles and mind-set variables where $5=$ strongly agree; $4=$ agree; $3=$ neutral; $2=$ disagree; $1=$ strongly disagree. The higher the mean score the more important the variable; $\alpha=$ Cronbach's Alpha coefficient 
Table VI: Correlations

\begin{tabular}{clcccccc}
\hline & & SL & AUL & DML & LFL & TFL & TSL \\
\hline \multirow{4}{*}{ GM } & Pearson & 0.066 & .066 & $.499^{* *}$ & .146 & $.315^{* *}$ & .080 \\
& correlation & .530 & .530 & .000 & .166 & .002 & .448 \\
& Sig. (2-tailed) & 92 & 92 & 92 & 92 & 92 & 92 \\
& N & & & & & & \\
\hline \multirow{2}{*}{ FM } & Pearson & $.235^{*}$ & $.235^{*}$ & -.069 & .154 & $-.205^{*}$ & .057 \\
& correlation & .024 & .024 & .513 & .143 & .050 & .589 \\
& Sig. (2-tailed) & 92 & 92 & 92 & 92 & 92 & 92 \\
& N & & & & & & \\
\hline
\end{tabular}

Notes: **. Correlation is significant at the 0.01 level $\left(2\right.$-tailed); ${ }^{*}$. Correlation is significant at the 0.05 level (2-tailed).

GM=Growth mindset; FM=Fixed mindset; $\mathbf{S L}=$ Situational Leadership; AUL=Autocratic Leadership; DML= Democratic Leadership; LFS=Laissez Faire Leadership;

TSL=Transactional Leadership; TFL=Transformational Leadership

Source: Author's Field data 